\author{
URSZULA JERUSZKA
}

Akademia Pedagogiki Specjalnej im. Marii Grzegorzewskiej

w Warszawie

\title{
OBSZARY PORADNICTWA I WSPARCIA SPOŁECZNEGO W ASPEKCIE POPRAWY ZATRUDNIALNOŚCI ABSOLWENTÓW SZKÓŁ ZAWODOWYCH
}

AвSTRACT. Jeruszka Urszula, Obszary poradnictwa $i$ wsparcia społecznego w aspekcie poprawy zatrudnialności absolwentów szkót zawodowych [Counseling and Social Support as Improving the Employability of Graduates of Vocational Schools]. Studia Edukacyjne nr 44, 2017, Poznań 2017, pp. 143-160. Adam Mickiewicz University Press. ISSN 1233-6688. DOI: 10.14746/se.2017.44.9

The text "Counseling and Social Support as Improving the Employability of Graduates of Vocational Schools" focuses on showing the causes of the low employability of graduates of vocational schools and the ways to help and support instruments for the graduates' successful entry into the labor market. This article interprets concepts of absolute and relative employability as well as learned helplessness on the labor market, which points to the need for differentiation. The text looks at the fate of professional graduate studies as a source of information about the demand for support activities career counseling and social support. The text moreover indicates problems corresponding not only to events occurring at one point in a person's life, but also the processes influencing the growth of the portion of the human capital related to education. Support measures are considered in relation to decisions affecting the educational path and professional graduate (prevention) and therefore the school-induced competence of entering the labor market (prevention of the negative consequences of differences between learning outcomes and employers' expectations).

Key words: human capital, vocational education, employability, support activities

\section{Wprowadzenie}

Jedną z barier pozyskania pracy przez absolwentów szkół zawodowych jest niedostosowanie podaży kompetencji zdobytych w szkole do potrzeb rynku pracy.

Zmiany na rynku pracy zachodzące w kolejnych okresach, istnienie rynku pracy wielu konkretnych zawodów, charakteryzujących się względną izolacją 
w stosunku do rynków pracy w innych zawodach, zmienność firm, ich celów i rodzajów działalności, zmiany samej pracy oraz metod i środków jej realizacji, nasilająca się konkurencja na rynkach pracy, a w konsekwencji zmiany kompetencyjnej struktury zatrudnienia, jak też zmiany preferencji ludzi, wzrost oczekiwań wobec pracy, jej rodzaju i warunków wykonywania mogą tłumaczyć potrzebę działań pomocowych (przekaz informacji, doradztwo, tutoring, coaching, mentoring...), adresowanych do uczniów i absolwentów szkół zawodowych $\mathrm{w}$ procesie przygotowywania do pracy i poszukiwania odpowiedniej pracy. Wypada też odnotować, iż zatrudnieniowa efektywność kształcenia jest kategorią dynamiczną.

Celem niniejszego opracowania jest przedstawienie zagadnień i problemów dotyczących zatrudnialności absolwentów szkół zawodowych osadzonych $w$ teorii kapitału ludzkiego oraz próba odpowiedzi na pytanie: jakie formy działań pomocowych mogą poprawić zatrudnialność absolwentów szkół zawodowych.

\section{Zatrudnialność absolutna i relatywna, wyuczona bezradność zatrudnieniowa}

Podejmując dyskusję na temat zatrudnialności absolwentów szkół zawodowych, należy ustalić, co rozumie się pod tym pojęciem. Zatrudnialność (employability) oznacza „zdolność do otrzymania, a także utrzymania satysfakcjonującej pracy najemnej lub pracy na własny rachunek oraz możliwości rozwoju kariery zawodowej". Celem jest optymalne wykorzystanie posiadanego potencjału kwalifikacji i kompetencji, a nie tylko znalezienie pracy. Definiując zatrudnialność, autorzy podkreślają trzy istotne cechy, a mianowicie: „potrzebę uzyskania od początku jakościowo znaczącego zatrudnienia lub samozatrudnienia, utrzymania zatrudnienia, a także umiejętność poruszania się na rynku pracy"1. Indywidualną zdolność do bycia zatrudnionym wyznaczają - przede wszystkim - układy umiejętności i wiedzy, postawy i zachowania, poziom osobistej motywacji do poszukiwania pracy, stopień „mobilności” jednostki w poszukiwaniu pracy oraz inne cechy osobowościowe, mentalne i socjodemograficzne niezbędne i pożądane w pracy związanej ze stanowiskiem, które ma objąć kandydat. Można sformułować tezę, że znalezienie zatrudnienia jest funkcją indywidualnej „,atrakcyjności zatrudnieniowej”.

Osiągnięcie stanu zatrudnienia jest wynikiem oddziaływania wielu czynników po stronie popytowej i podażowej rynku pracy, które pozwalają konkretnej osobie podejmować i utrzymywać zatrudnienie, a także rozwijać

${ }^{1}$ M. Juchnowicz, Sektorowe badania podaży i popytu na kwalifikacje i kompetencje, Edukacja Ekonomistów i Menadżerów, 2014, 2(32), s. 13. 
karierę zawodową. Wśród nich coraz większego znaczenia nabiera - przekonuje wielu badaczy - dostosowanie systemu edukacji do dynamicznie zmieniającego się rynku pracy, a w konsekwencji dopasowanie kompetencji zdobytych w szkole do wymagań pracodawców i potrzeb gospodarki (rynku pracy). Natychmiast pojawia się pytanie: czy - i w jakiej mierze - jest możliwe dopasowanie kompetencji absolwentów szkół do potrzeb rynku pracy. W rzeczywistości gospodarczej można bowiem wyodrębnić wiele rodzajów rynków pracy ${ }^{2}$, a jedną z cech formalnej edukacji szkolnej jest swoista inercja. Nietrudno też dostrzec, iż dopasowanie kompetencji absolwentów do stanowiska czy raczej rodzaju pracy powinno być osiągane w odpowiednich ramach czasowych. Kompetencje podlegają bowiem zmianom (mogą być powiększane, jak też ulegać deprecjacji), a w konsekwencji zmienia się ich przydatność na rynku pracy. Pojawia się więc kolejne pytanie: w jakim stopniu wysoka atrakcyjność zatrudnieniowa dziś będzie także wysoką atrakcyjnością zatrudnieniową jutro, za miesiąc, za rok.

Istotnym czynnikiem zatrudnialności absolwentów są uwarunkowania rynku pracy. Te zewnętrzne przyczyny, w zależności od ich natężenia i charakteru, mogą wywierać silny wpływ na zatrudnialność, umniejszając determinanty zatrudnialności wynikające z obiektywnego poziomu kwalifikacji/ kompetencji absolwentów, poziomu określonego przez podstawy programowe kształcenia w zawodach oraz przez krajowe standardy kwalifikacji/kompetencji zawodowych. Kiedy praca jest łatwo dostępna, znalezienie zatrudnienia jest relatywnie proste. W sytuacji deficytu miejsc pracy pracodawcy mogą pozwolić sobie na większą selekcję pod kątem poziomu umiejętności, wykształcenia, czy też doświadczenia zawodowego. Tak więc uwarunkowania rynku pracy, niepodlegające kontroli przez danego absolwenta, są znaczącym czynnikiem wyznaczającym zarówno ogólną zatrudnialność, jak również prawdopodobieństwo znalezienia zatrudnienia przez potencjalnie atrakcyjne zatrudnieniowo osoby.

Zatrudnialność warunkuje nie tylko obiektywny poziom kwalifikacji/ kompetencji i stopień spełnienia wymagań określonej pracy, ale również re-

\footnotetext{
${ }^{2}$ Podstawowe znaczenie mają dwa wymiary analizy rynków pracy: wymiar przestrzenny (geograficzny) i wymiar kwalifikacyjno-zawodowy. Biorąc pod uwagę wymiar przestrzenny, można rozróżnić: międzynarodowy, ogólnokrajowy, regionalny i lokalny rynek pracy. Ten ostatni ma duże znaczenie dla zatrudnialności ze względu na istnienie barier instytucjonalnych i ekonomicznych ograniczających mobilność pracowników. Lokalny rynek pracy można zdefiniować jako „obszar geograficzny, w obrębie którego informacje o miejscach pracy i szukających pracy są prawie doskonałe, zaś koszty poszukiwań pracy i dojazdów do pracy stosunkowo niskie. Jednostkami administracyjnymi zbliżonymi najbardziej do koncepcji lokalnych rynków pracy są w Polsce powiaty i gminy. (...) Biorąc pod uwagę wymiar kwalifikacyjno-zawodowy, można wyodrębnić rynki pracy poszczególnych zawodów" (E. Kryńska, E. Kwiatkowski, Podstawy wiedzy o rynku pracy, Łódź 2013, s. 18-19).
} 
latywną atrakcyjność zatrudnieniową w porównaniu z innymi osobami poszukującymi pracy. Atrakcyjność zatrudnieniowa zależy więc również od tego, jak dobry jest absolwent szkoły w porównaniu z innymi poszukującymi pracy. To, jakie stanowisko obejmie kandydat zależy od jego relatywnej pozycji na rynku pracy. Ta z kolei zależy między innymi od kwalifikacji, których głównym miernikiem jest poziom wykształcenia. $Z$ tego punktu widzenia możliwe jest mówienie o zatrudnialności w dwóch wymiarach - absolutnej i relatywnej atrakcyjności zatrudnieniowej ${ }^{3}$. Posiadanie odpowiednich umiejętności, postaw i doświadczenia związanych z wykonywaniem określonych czynności zawodowych - wspierających absolutną zatrudnialność - nie determinuje relatywnej zatrudnialności, a tym samym nie gwarantuje znalezienia zatrudnienia. W niesprzyjających warunkach rynku pracy nawet najbardziej atrakcyjna zatrudnieniowo osoba może mieć trudności ze znalezieniem odpowiedniej pracy. Skupienie się na atrakcyjności zatrudnieniowej jako na właściwości absolwenta zależnej od indywidualnych czynników przysłania fakt, że jest ona funkcją zarówno strony podażowej, jak i popytowej rynku pracy. Posiadanie odpowiednich kwalifikacji/kompetencji doprowadzi do uzyskania odpowiedniego zatrudnienia jedynie wówczas, kiedy będzie istniał odpowiadający im popyt ze strony pracodawców.

Warto rozważyć, jako ilustrację badań mających na celu wyjaśnienie przyczyn bezskutecznego poszukiwania pracy przez absolwentów szkół zawodowych, pojęcie wyuczonej bezradności zatrudnieniowej. Opisuje ono nieadekwatną bierność i zmniejszony wysiłek, które są rezultatem powtarzającego się doświadczenia negatywnych zdarzeń odnoszących się do stosowanych w praktyce organizacyjnej procedur doboru pracowników. W modelu wyuczonej bezradności wyodrębniono trzy wymiary atrybucyjne bezskutecznego poszukiwania pracy: wewnętrzne (osobowe); zewnętrzne (sytuacyjne); specyficzne (ogólne, stabilne - niestabilne) ${ }^{4}$. Zjawisko wyuczonej bezradności zatrudnieniowej może wyjaśniać fakt, że absolwent szkoły zawodowej uczy się, iż poszukiwanie pracy nie wpływa na rezultaty tego poszukiwania. Szacuje, że przyczyna bezskutecznego poszukiwania pracy związana jest $\mathrm{z}$,czymś" w nim samym, ale także z „czymś”, co dotyczy innych ludzi lub okoliczności i sytuacji na rynku pracy. Absolwent bezskutecznie poszukujący pracy $\mathrm{w}$ niskim stopniu odbiera proces selekcji jako uczciwy. Wyuczył się, że jest bezradny wobec braku ofert pracy dla niego, że w niskim stopniu ma wpływ na własne zatrudnienie. Oczekiwanie, iż rezultaty są niezależne od zachowania absolwenta ma implikacje motywacyjne, poznawcze i emocjonalne:

\footnotetext{
${ }^{3}$ Por.: M. Gruza, Zatrudnialność absolwentów szkót zawodowych, [w:] Unowocześnianie metod i form ksztatcenia zawodowego w Polsce. Diagnoza i oczekiwane kierunki zmian, red. U. Jeruszka, Warszawa 2012, s. 68-69.

${ }^{4}$ L.A. Pervin, O.P. John, Osobowość. Teoria i badania, New York 2001 - Kraków 2002, s. 49.
} 
1) niekontrolowane zdarzenia bezskutecznego poszukiwania pracy podważają motywację absolwenta do inicjowania poszukiwań $u$ innych pracodawców, które mogłyby prowadzić w efekcie do zatrudnienia; 2) w rezultacie braku kontroli nad wcześniejszymi negatywnymi zdarzeniami bezskutecznego poszukiwania pracy absolwent z trudnością uczy się, że jego kompetencje zawodowe mogą mieć wpływ na inne procesy rekrutacji i selekcji oraz, co za tym idzie, decyzje innych potencjalnych pracodawców o przyjęciu do pracy; 3) powtarzające się doświadczenia z niekontrolowanymi zdarzeniami związanymi z nieprzyjęciem do pracy prowadzić mogą ostatecznie do powstania stanu emocjonalnego podobnego do tego, jaki u ludzi określa się jako depresję (łączy się depresję z przedłużającym się stresem i poczuciem porażki).

\section{Kompetencje a kwalifikacje i kapitał ludzki}

W badaniach ulokowanych w naukach społecznych - a pedagogika należy do nauk społecznych - coraz większe znaczenie przypisuje się teorii kapitału ludzkiego, stworzonej i rozwijanej od wczesnych lat 60. minionego wieku przez ekonomistów amerykańskich. Ekonomia, a zwłaszcza ekonomika kształcenia należy do nauk pomocniczych i współdziałających z pedagogiką. Bywa, że punkt wyjścia do prezentowanych przez pedagogów analiz stanowi perspektywa ekonomiczna ${ }^{5}$. Tak też jest i w niniejszym opracowaniu.

Nie widać powodów, dla których należałoby kwestionować próby stosowania podejścia ekonomicznego do objaśniania zjawisk czy procesów ściśle powiązanych z pedagogiką, takich - na przykład - jak oferta edukacyjna, popyt na określone kompetencje, efektywność kształcenia, rynek edukacyjny, dobór pracowników, przebieg ścieżek edukacyjnych i zawodowych absolwentów szkół, dynamika demograficzna, czy wysokość publicznych i prywatnych nakładów na edukację. Te ostatnie utarło się nazywać inwestowaniem w kapitał ludzki. Według Gary'ego S. Beckera,

\footnotetext{
${ }^{5} \mathrm{~K}$. Denek koncepcję kapitału ludzkiego rozwijał w obszarze edukacji i nauk o niej. Opisywał kształcenie z perspektywy kapitału ludzkiego i uzasadniał, iż „Dokonane przez taki opis kształcenie staje się czytelne dla osób zajmujących się edukacją. Dzięki temu ułatwia nie tylko im porozumiewanie się między sobą, lecz także z partnerami zainteresowanymi podażą usług edukacyjnych. Stwarza to należytą podstawę do prowadzenia właściwej polityki edukacyjnej i integrowania jej z poszczególnymi sektorami, sferami, działami i gałęziami gospodarki narodowej. Planując ją można ocenić, czy oferta ta co do poziomów i kierunków kształcenia odpowiada popytowi, a kompetencje tworzone przez szkoły są zgodne - co do treści i liczby absolwentów - z potrzebami rynku pracy" (K. Denek, Ku dobrej edukacji, Toruń 2005, s. 91). M. Malewski źródeł rosnącej popularności koncepcji kształcenia ustawicznego doszukiwał się w teorii kapitału ludzkiego. Analizował pomnażany przez edukację kapitał ludzki z perspektywy makrostrukturalnej i mikrostrukturalnej (M. Malewski, Od nauczania do uczenia się. O paradygmatycznej zmianie w andragogice, Wrocław 2010, s. 49 i n.).
} 
Wykształcenie i szkolenie zawodowe to najważniejsze inwestycje w kapitał ludzki. (...) Każda osoba wytwarza swój własny kapitał ludzki poprzez wykorzystywanie części swego czasu i towarów na "chodzenie do szkoły”, podnoszenie kwalifikacji $\mathrm{w}$ trakcie pracy zawodowej itd. ${ }^{6}$

W literaturze przedmiotu można znaleźć wiele definicji kapitału ludzkiego. Godna szczególnej uwagi jest definicja mówiąca, iż „kapitał ludzki” to ogół wrodzonych i nabytych właściwości, do których zaliczamy zdolności, wiedzę, umiejętności, doświadczenie, zdrowie, cechy osobowości, postawy i zachowania i inne wartości ucieleśnione w ludziach, zarówno te realnie istniejące, jak i potencjalne, które są wykorzystywane i doskonalone w całym okresie aktywności zawodowej oraz które stanowią źródło aktualnych i przyszłych wartości finansowych ${ }^{7}$. Kapitał ludzki nie jest dany przez genetyczne właściwości danej populacji. Kapitał ludzki nie jest zasobem stałym, można go powiększać za pomocą inwestowania w człowieka. Powiększanie zasobów ucieleśnionych $\mathrm{w}$ ludziach dokonuje się między innymi poprzez usługi i udogodnienia związane z ochroną zdrowia, poprawą wyżywienia, kształcenie w systemie edukacji, szkolenie i doskonalenie zawodowe w czasie pracy, poszukiwanie i gromadzenie informacji o sytuacji firm i perspektywach zawodowych. Odpowiedni poziom kapitału ludzkiego jest źródłem przewagi konkurencyjnej. Poziom kapitału ludzkiego odnosi się do poziomu kompetencji.

Istnieją różne - szersze i węższe - definicje kompetencji.

Szerokie rozumienie kompetencji zbliża je do pojęcia kapitału ludzkiego. Termin „kompetencje” - w szerszym znaczeniu - traktowany jest niemal jako synonim terminu "kapitał ludzki”, definiowanego z pozycji jednostkowych (indywidualnych pracowników). Ujmując rzecz szerzej, można przyjąć, że kompetencje

obejmują: wewnętrzną motywację, uzdolnienia i predyspozycje, wiedzę, doświadczenie i praktyczne umiejętności, zdrowie i kondycję, inne cechy psychofizyczne ważne z punktu widzenia procesów pracy, postawy i zachowania oczekiwane w miejscu zatrudnienia, a także formalne uprawnienia do działania ${ }^{8}$.

Należy zgodzić się z T. Oleksynem, który twierdzi, że:

Uprawnione jest stwierdzenie, że szeroko rozumiane kompetencje pracowników i kapitał ludzki pracowników są tym samym - zwłaszcza, gdy za elementy kompetencji

${ }^{6}$ G.S. Becker, Ekonomiczna teoria zachowań ludzkich, przekł. H. Hagemejerowa, K. Hagemejer, Warszawa 1990, s. 217.

7 A. Pocztowski, Strategiczne aspekty rozwoju zasobów ludzkich, [w:] Przyszłość pracy w XXI wieku, red. S. Borkowska, Warszawa 2004, s. 191-192.

${ }^{8}$ T. Oleksyn, Zarządzanie kompetencjami. Teoria i praktyka, Kraków 2006, s. 25. 
uznaje się stan zdrowia i przydatność do pracy ze względu na wiek. Trudno jednak nie brać pod uwagę obu tych czynników, gdy mówimy o kompetencjach" ${ }^{\prime \prime}$.

Kompetencje w węższym znaczeniu definiuje się jako faktycznie posiadaną wiedzę, umiejętności i postawy umożliwiające wykonywanie określonych czynności zawodowych. Nie ma znaczenia, w jakim trybie zostały one nabyte i czy są potwierdzone w wyniku procedury walidacyjnej ${ }^{10}$.

Warto zwrócić uwagę na fakt rozróżniania pojęcia kompetencji od pojęcia kwalifikacji. Kwalifikacje są określane jako potwierdzone w procesie formalnej procedury walidacyjnej i udokumentowane kompetencje. Najbardziej powszechnym przykładem kwalifikacji jest dyplom ukończenia szkoły (wykształcenie). Poziom kwalifikacji jest tylko niedoskonałym miernikiem faktycznie posiadanych kompetencji.

Teoretycy kapitału ludzkiego odróżniają niedopasowanie kwalifikacyjne od niedopasowania kompetencyjnego. Pierwszy typ dotyczy niezgodności między formalnie posiadanym wykształceniem a charakterystyką stanowiska pracy (poziom wykształcenia danej osoby jest wyższy/niższy niż wymagany do określonej pracy), drugi odnosi się do niedopasowania w zakresie faktycznie posiadanych kompetencji (kompetencje danej osoby są zbyt niskie wobec wymagań pracodawców lub są innego rodzaju niż te, jakich pracodawcy oczekiwaliby od pracownika na określonych stanowiskach).

\section{Praktyczna wartość badania losów zawodowych absolwentów szkół}

Badania losów zawodowych absolwentów prowadzone są na różnych poziomach kształcenia, oparte na różnych narzędziach badawczych, w różnej skali i przez różne jednostki badawcze. Inna jest też ich użyteczność. Niektóre są częścią empiryczną prac na stopień (licencjackich, magisterskich, doktorskich), inne powstają na zapotrzebowanie władz oświatowych/szkoły/ uczelni i wyniki badań stanowią dla nich informację - ocenę realizowanego programu, a także ocenę stanu przygotowania absolwentów do pracy w zawodzie. Dzięki zgromadzonym informacjom szkoły mają lepiej dopasować programy nauczania do zmieniających się wymogów rynku pracy. Wyniki tego typu badań mogą służyć do monitorowania rynku pracy dla potrzeb edukacji, rozpoznaniu sytuacji społecznej, zawodowej i bytowej absolwentów. Stanowią one również źródło informacji o zapotrzebowaniu uczniów

\footnotetext{
${ }^{9}$ Tamże, s. 26.

${ }^{10}$ Por. J. Górniak (red.), Kompetencje jako klucz do rozwoju Polski, Warszawa 2012, s. 23; D. Buttler, Studenci, pracodawcy, wykładowy - różne wizje kompetentnego pracownika, Edukacja Ekonomistów i Menadżerów, 2012, 3(24), s. 46.
} 
i absolwentów na działania pomocowe z zakresu poradnictwa i wsparcia społecznego. Są one istotne, gdyż mogą stać się podstawą ustalania słusznych i skutecznych form działań pomocnych w podejmowaniu decyzji kształtujących ścieżkę edukacyjną i zawodową absolwenta, stać się przesłankami zmian, dyrektywami działania pedagogicznego zapobiegającymi - w miarę przyrostu kapitału ludzkiego - negatywnym konsekwencjom rozbieżności między efektami kształcenia a oczekiwaniami pracodawców.

Nie wdając się w metodyczne i kalkulacyjne złożoności, badania wśród absolwentów szkół stanowią także próbę sformułowania sądów wartościujących związanych z zapotrzebowaniem na działania pomocowe, wspierające rozwój kariery zawodowej.

Ogólnie rzecz biorąc, badania losów zawodowych absolwentów szkół służą wykryciu mechanizmów odpowiadających za przyrost kapitału ludzkiego na etapie kształcenia szkolnego oraz ocenie jakości rynkowej kapitału ludzkiego absolwentów. Wydaje się też ważne ustalenie, w jaki sposób absolwenci interpretują brak możliwości znalezienia pracy po ukończeniu szkoły i podstawy ich bezradności zatrudnieniowej.

\section{Niedopasowania kompetencyjne i kwalifikacyjne absolwentów szkół zawodowych}

Koncepcja kapitału ludzkiego stała się punktem wyjścia dla postawienia pytania, czy - i w jakiej mierze - kapitał ludzki rozumiany jako wyposażenie, z którym absolwenci szkół wchodzą na rynek pracy przynosi „zwrot” w postaci zatrudnienia i wynagrodzenia w wysokości adekwatnej do ekonomicznej wartości tego kapitału.

Powtarzana powszechnie teza: „inwestycje w kapitał ludzki są naszą szansą rozwojową" okazuje się mniej oczywista niż mogłoby się wydawać. Kwestionując pogląd mówiący, że ludzie lepiej wykształceni łatwiej pozyskują zatrudnienie i otrzymują też wyższe wynagrodzenie, K. Frieske powiada:

po pierwsze - wyższe wynagrodzenia uzyskiwane przez pracowników lepiej wy-
kształconych mogą być nie tyle funkcją ich wyższych kwalifikacji, ile sygnalizować
pracodawcy gotowość do osobistego rozwoju lub talenty czy cnoty, których wyma-
gało uzyskanie tych kwalifikacji. Po drugie - jeśli coraz lepiej wykwalifikowani pra-
cownicy nie mają gdzie ulokować swoich kwalifikacji, bo poprawa poziomu wykształ-
cenia jest szybsza aniżeli przyrost liczby odpowiednich stanowisk pracy, to można
oczekiwać, że stopa zwrotu w inwestycje edukacyjne będzie szybko malała. Wreszcie,
po trzecie - może się też okazać, że wzrost wykształcenia w przypadku poszczegól-
nych jednostek rzeczywiście przyczynia się do wzrostu ich wynagrodzeń, ale rodzaj
tego wykształcenia powoduje, że lokują się one, na przykład, w administracji publicz- 
nej, co uruchamia biurokratyczne przerosty, które bardziej blokują, aniżeli ułatwiają działalność gospodarczą ${ }^{11}$.

Nie ma powodów, aby ostatnie z tych uwag lekceważyć, zwłaszcza kiedy dostrzega się to, że - wedle danych GUS - około $44 \%$ pracujących Polaków wykonuje pracę niezgodną $\mathrm{z}$ kierunkiem wykształcenia, $\mathrm{w}$ tym $\mathrm{z}$ wykształceniem zasadniczym - 38\%, średnim - $46 \%$, wyższym - 47\% tylko dlatego, że nie mogło jej znaleźć. To, powiedziałby M. Kabaj, marnotrawienie kapitału ludzkiego związane ze strukturalnymi niedopasowaniami na rynku pracy, z brakiem koordynacji edukacji zawodowej i rynku pracy, z brakiem mobilności itp. Wgląd w dane GUS-u mówi o czymś jeszcze: okazuje się, że 56\% pracujących Polaków nigdy (!) nie pracowało w wyuczonym zawodzie, w tym z wykształceniem zasadniczym $-39 \%$, średnim $-62 \%$, wyższym $-72 \%{ }^{12}$.

Analizy empiryczne wspierają rację o negatywnej korelacji między inwestowaniem w kapitał ludzki i wzrostem wskaźnika zatrudnienia. Średni okres przejścia absolwenta ze szkoły do pracy wynosi rok, przy czym formuła tego uśrednienia jest lokalna i historycznie zmienna. Okres poszukiwania pierwszej pracy przez absolwentów szkół zawodowych jest zróżnicowany, uzależniony - także - od poziomu wykształcenia i zawodu. W pół roku po ukończeniu szkoły zatrudnienie znajduje około $3 / 4$ absolwentów w zawodach o charakterze technicznym lub usługowym. Blisko 10\% absolwentów poszukuje pracy od roku do 2 lat, natomiast aż około 9\% - powyżej 2 lat. Na czołowe miejsce przyczyn, dla których absolwenci nie mogą znaleźć pracy wybija się, w opinii absolwentów - brak ofert pracy, w opinii pracodawców - brak etatów ${ }^{13}$.

Stopa bezrobocia wśród młodych osób (do poniżej 25. roku życia) w Polsce w trzecim kwartale 2013 roku wynosiła 28,1\%. Oznacza to, że co czwarty aktywny zawodowo młody Polak pozostaje bez pracy. Dyplomy ukończenia szkól, także wyższych, z punktu widzenia rynku pracy mają niewielką wartość. Bezrobotni absolwenci rejestrują się w urzędach pracy. Fakt kierowania absolwentów szkół zawodowych bezpośrednio po ukończeniu nauki na szkolenie zawodowe jest wymowną ilustracją braku możliwości absorpcyjnych polskiego rynku pracy, ale też niedostosowania systemu szkolnictwa zawodowego do jego potrzeb. Obserwowany paradoks polega na tym, że $\mathrm{w}$ warunkach wysokiego bezrobocia, przy stopie bezrobocia ogółem w granicach $13-14 \%$ w Polsce i około $11 \%$ w UE, wiele stanowisk pracy pozostaje

${ }^{11}$ K.W. Frieske, Kapitał ludzki: teoria czy doktryna? [w:] Rynek pracy i wykorzystanie potencjatu pracy w Polsce, red. A. Rajkiewicz, J. Orczyk, Warszawa 2014, s. 170.

${ }^{12}$ GUS, Wybory ścieżki kształcenia a sytuacja zawodowa Polaków, Warszawa 2013, s. 103, tabela $1(42)$ i 2(43) oraz s. 117, tabela 11(52).

${ }^{13}$ U. Jeruszka red., Unowocześnianie metod i form ksztatcenia zawodowego, s. 277-281, tabela 19.2 i 19.3. 
nieobsadzonych. Pracodawcy mają kłopoty z dostępnością odpowiednio wykształconych pracowników.

Wynikiem strukturalnych niedopasowań jest nie tylko bezrobocie, lecz także zjawisko przeedukowania (overeducation), czyli nadwyżki wykształcenia w stosunku do kwalifikacji rzeczywiście potrzebnych do wykonywania określonych zadań ${ }^{14}$. Na pracę poniżej kwalifikacji narażone są szczególnie osoby poniżej 21-25 lat.

Wypada także odnotować, że badacze zagadnień społecznych rozróżniają niedopasowanie pionowe (wertykalne) i poziome (horyzontalne). Z niedopasowaniem pionowym mamy do czynienia wówczas, gdy kwalifikacje/kompetencje danej osoby są zbyt niskie lub zbyt wysokie w stosunku do wymaganych na stanowisku pracy. W pierwszym przypadku mówi się o nadwyżce kompetencyjnej/kwalifikacyjnej, natomiast w drugim - o niedoborze kompetencyjnym/kwalifikacyjnym. Niedopasowanie poziome dotyczy osób, które wykonują pracę niezgodną z kierunkiem/profilem wykształcenia.

W wielu krajach, także w Polsce, mamy do czynienia ze zjawiskiem overeducation. Wyniki badań wykazują, że nadwyżka kwalifikacji jest zjawiskiem występującym w Polsce na dość znaczną skalę - odsetek osób w wieku 2125 lat pracujących poniżej kwalifikacji w latach 1988-2008 mieścił się w przedziale między $11 \%$ a $34 \%$ oraz charakteryzuje się dość dużą trwałością - od końca lat 90. mniej więcej co dziesiąty pracownik znajdował się w sytuacji względnie trwałej, bo trwającej co najmniej pięć lat nadwyżki wykształcenia ${ }^{15}$. Nadmiar wykształcenia stanowi względnie trwały element indywidualnych biografii zawodowych. Konsekwencjami tego zjawiska są niższe wynagrodzenia i niższy poziom satysfakcji zawodowej. Wykonywanie pracy poniżej własnych możliwości prowadzi do ograniczenia efektywności pracownika. Wszelkie niedopasowania pracy do kompetencji, w tym oczekiwań i aspiracji pracowników wobec pracy, zazwyczaj wywierają niekorzystny wpływ na ich psychikę. Osoby wykonujące zadania niezgodne z ich kompetencjami czy kwalifikacjami są również bardziej skłonne do rezygnacji z pracy.

Nadwyżka wykształcenia niejednokrotnie nabiera charakteru „ślepego zaułka". Absolwenci, którym nie uda się podjąć odpowiedniej pracy, nie są

${ }^{14}$ Problem nadwyżki kwalifikacji czy wykształcenia nasilił się w krajach rozwiniętych $\mathrm{w}$ drugiej połowie XX wieku wraz z upowszechnieniem się kształcenia na poziomie średnim i wyższym. W przypadku wielu krajów współczynnik scholaryzacji na poziomie wyższym wzrastał szybciej niż zapotrzebowanie na wysoko wykwalifikowanych pracowników. Z uwagi na gwałtowny wzrost podaży absolwentów wyższych uczelni często przyjmuje się, iż właśnie ta grupa jest najbardziej zagrożona nadwyżką kwalifikacji.

${ }^{15}$ Por.: A. Kiersztyn, Racjonalne inwestycje czy złudne nadzieje: nadwyżka wykształcenia na polskim rynku pracy, Polityka Społeczna, 2011, 1, s. 7-14; M. Juchnowicz, Sektorowe badania podaży i popytu na kwalifikacje i kompetencje, Edukacja Ekonomistów i Menadżerów, 2014, 2(32), s. 11-21; D. Buttler, Niedopasowania kompetencyjne i kwalifikacyjne absolwentów Uniwersytetu Ekonomicznego w Poznaniu, Edukacja Ekonomistów i Menadżerów, 2014, 2(32), s. 127-143. 
później w stanie skutecznie konkurować z tymi, którzy znaleźli zatrudnienie pasujące do kwalifikacji, przeszli dodatkowe szkolenia w miejscu pracy i mogą wykazać się odpowiednim stażem w swoim zawodzie.

\section{Działania pomocowe i wspierające}

Skoro nie wszystkie inwestycje w kapitał ludzki prowadzą do zatrudnienia, skoro trudno dostosować strukturę i treści kształcenia zawodowego do zmieniającej się kompetencyjnej struktury popytu na pracę, skoro absolwenci szkół zawodowych mają problemy z pozyskaniem pracy, a znaczny odsetek $\mathrm{z}$ nich podejmuje pracę na stanowiskach o niższych wymaganiach kwalifikacyjnych niż kwalifikacje absolwenta lub podejmuje pracę niezgodną z kierunkiem wykształcenia, to trzeba skupić się na „czymś” innym - na działaniach „pomocowych” podejmowanych na rzecz poprawy zatrudnialności absolwentów szkół zawodowych.

Do głównych obszarów działań pomocowych należą:

- Poradnictwo na etapie wyboru kierunku kształcenia i zawodu

Wybór zawodu nie powinien być tylko jednorazowym aktem, ale procesem - tylko już uzewnętrznionym zakończeniem długotrwałego procesu i jakość (efekt) tego finalnego momentu zależy od tego, jak człowiek podejmujący decyzję zawodową jest do tego przygotowany. Aby w odpowiednich momentach podejmować właściwe decyzje, trzeba to umieć zrobić, uczyć się tego, należy się w tym ćwiczyć. Jest to jedno z zadań szkolnego doradcy zawodowego.

Decyzja zawodowa w gimnazjum stanowi pierwszą poważną decyzję, której skutki rzutują na całe życie człowieka. Zachodzi konieczność rozpoznawania cech osobowościowych, predyspozycji oraz potencjału rozwojowego kandydatów do szkół zawodowych. Oznacza to, że na etapie wyboru kierunku edukacji potrzebni są doradcy zawodowi pomocni w identyfikacji predyspozycji uczniów do wykonywania zawodu związanego z planowanym kierunkiem kształcenia. Niewłaściwy wybór zawodu, niezgodny z predyspozycjami i preferencjami ucznia, może prowadzić do marnotrawstwa inwestycji w powiększanie kapitału ludzkiego w czasie nauki w szkole zawodowej.

Myślenie o rynkowej funkcji wykształcenia jest w sposób oczywisty sprzęnięte $\mathrm{z}$ prognozowaniem popytu na pracę. Działania podejmowane w ramach polityki edukacyjnej i podporządkowane im decyzje zawodowe powinny, z natury rzeczy, wynikać z przewidywanych zmian zapotrzebowania na kadry w okresach przyszłych. Perspektywiczna koordynacja edu- 
kacji zawodowej i rynku pracy zapewnia - twierdzi M. Kabaj ${ }^{16}$ - prowadzenie stałych studiów nad perspektywiczną ewolucją zawodów i ich strukturą oraz opracowanie prognozy zapotrzebowania na kadry w przekrojach przestrzennych i kwalifikacyjno-zawodowych. Owa perspektywiczna koordynacja umożliwia prognozowanie zawodów deficytowych ${ }^{17}$ na lokalnym rynku pracy i - co za tym idzie - udzielanie porad młodzieży, aby - uwzględniając indywidualne cechy osobowościowe i predyspozycje do pracy - wybierała zawody, na które - zakłada się - że podaż przewyższy popyt. Niewiedza uczniów o wymaganiach pracodawców może prowadzić do nieefektywnych inwestycji w kapitał ludzki.

Wszystkie te elementy (a więc zarówno elementy strony podażowej, jak i popytowej) wpływają na wybory zawodowe młodych ludzi, w jakich kierunkach i zawodach podjąć naukę.

- Praca nauczyciela z uczniami wspierająca rozwój osobowy uczniów

W kształceniu ważna jest nie tylko jego treść, ale także sposób. Warto dostrzegać potrzebę działań mających na celu stymulację przekształceń w świadomości młodzieży. Po pierwsze, chodzi o przygotowanie młodych ludzi do przyszłego uczestnictwa $\mathrm{w}$ transakcjach rynku pracy, o informowanie ich o funkcjonowaniu rynku pracy, o sposobach poprawiania swojej pozycji zawodowej, że w przyszłości będą musieli dostosowywać się do zmian zapotrzebowania na pracę, ale też zmian samej pracy oraz metod i środków jej realizacji. Po drugie, chodzi o wyzwolenie uczniów z zależności od syndromu wyuczonej (odczuwanej) bezradności zatrudnieniowej. Mogą to zrobić nauczyciele, dobierając odpowiednie sposoby kształtowania u uczniów wiary $\mathrm{w}$ siebie, wiary we własne siły, wiary $\mathrm{w}$ szanse zdobycia pracy $\mathrm{w}$ wyuczonym zawodzie, pewności siebie, optymizmu i pozytywnego myślenia, tworząc jednocześnie pozytywne nastawienie wobec sytuacji uprzednio wywołujących lęk. Chodzi o postępowanie pedagogiczne wspierające rozwój u ucznia akceptacji siebie, traktowania siebie jako osoby wartościowej, przyjmowanie odpowiedzialności za swoje działanie, silnej motywacji do działania i do ryzyka, śmiałości, swobody i spontaniczności w działaniu, wyrażanie samego siebie bez niepotrzebnej obawy o to, co powiedzą inni. Nie warto może wgłębiać się $\mathrm{w}$ inne wątki analizy rozwoju samoświadomości uczniów (samoświadomości samego siebie), dość powiedzieć, że wysiłek wkładany

\footnotetext{
${ }^{16}$ M. Kabaj, Projekt systemu integracji edukacji zawodowej i rynku pracy. W kierunku ksztatcenia dualnego, Polityka Społeczna, 1998, 9, s. 7.

${ }^{17}$ Zawody deficytowe to zawody, na które występuje większe zapotrzebowanie niż liczba osób poszukujących pracy, to znaczy na rynku jest więcej ofert pracy niż wynosi liczba bezrobotnych i absolwentów.
} 
w nabywanie tych właściwości i osiągnięcie odpowiedniego stopnia rozwoju samoświadomości mogą wspierać mądrzy nauczyciele kształcenia zawodowego - tutorzy.

Oczywiście zakłada się, iż nauczyciel-tutor wspiera ucznia w procesie uczenia się w wybranym obszarze wiedzy, pomaga rozwinąć umiejętności samodzielnego jej zdobywania oraz pogłębić sztukę maksymalnego korzystania z własnych talentów. Nauczyciel-tutor udziela uczniom takiej pomocy, aby potrafili pomagać samym sobie. Ma za zadanie prowadzić ucznia do mądrości i dojrzałości, aby w konsekwencji jego zachowanie stało się dojrzałe i konstruktywne. Tutoring szkolny - między innymi - optymalizuje funkcjonowanie ucznia bazujące na wykorzystaniu jego wewnętrznych zasobów i posiadanego potencjału rozwojowego (jego talentów, mocnych i słabych stron, preferowanych stylów uczenia się, wartości). Uczy merytorycznej obrony własnej opinii oraz prawidłowego oceniania swoich możliwości. Następstwem trafnej (adekwatnej, umiarkowanie wysokiej) samooceny jest podejmowanie zadań odpowiadających możliwościom, co pozwala na uniknięcie niepowodzeń i zabezpiecza jednostkę ludzką przed przykrymi doznaniami emocjonalnymi, marnotrawstwem wysiłku itp. Dzięki rzetelnemu i inspirującemu tutorialowi uczeń może się rozwijać naukowo i osobowościowo, nabierając pewności siebie i rozwijając wartościowe, szlachetne cechy charakteru, cechy niezbędne i pożądane w pracy związanej z nauczanym zawodem.

- Pomoc ze strony szkoły w znalezieniu podmiotu przyjmującego ucznia na praktykę zawodową

Coraz powszechniejszy staje się postulat dotyczący obowiązkowych praktyk zawodowych u pracodawców ${ }^{18}$. Praktyka w zakładach pracy umożliwia łączenie nauki i pracy, ale nade wszystko zdobycie doświadczenia i wiedzy praktycznej, kształtowanie umiejętności tzw. twardych (funkcjonalnych) oraz umiejętności tzw. miękkich (behawioralnych). Uczniowie-praktykanci mogą nie tyko poznać pracę i nauczyć się ją wykonywać w rzeczywistych warunkach, ale też poznać pracodawcę i dać się poznać pracodawcy, który - gdy praktykant przejawia cechy i umiejętności jakich pracodawca oczekuje

${ }^{18}$ Praktyki zawodowe organizuje się dla uczniów w celu zastosowania i pogłębienia zdobytej wiedzy oraz umiejętności zawodowych w rzeczywistych warunkach pracy. Praktyki zawodowe mogą być organizowane u pracodawców, indywidualnych gospodarzy rolnych lub u innych podmiotów, czyli w warsztatach szkolnych, pracowniach szkolnych, szkolnych gospodarstwach pomocniczych, centrach kształcenia praktycznego, centrach kształcenia ustawicznego. Warunki stwarzane przez wymienione inne podmioty są „rzeczywistymi warunkami pracy" wyłącznie z nazwy. Możliwość realizacji praktyk zawodowych nie tylko u pracodawców, ale też w „innych podmiotach" oznacza, że uczeń może zdobyć wykształcenie zawodowe nie spędzając ani jednego dnia u pracodawcy (w zakładzie pracy). 
- może mu zaproponować pracę. Bardzo często praktykanci już jako absolwenci pozyskują zatrudnienie w miejscu odbywania praktyk.

Kłopot z praktykami jest taki, że - niezależnie od zawodu - trudno znaleźć pracodawcę, który przyjąłby uczniów na praktykę zawodową. Współpraca szkół i zakładów pracy w zakresie realizacji praktycznej nauki zawodu napotyka bariery, głównie o charakterze prawnym i finansowym, jednak jest to już wątek osobny i wart osobnego rozważenia.

Zdarza się, iż - może, aby maskować bezradność szkoły w borykaniu się z organizacją i realizacją praktyk - szkoła oczekuje, że uczeń sam dla siebie znajdzie miejsce odbywania praktyki. Uczniowie mają możliwość realizacji praktyk w placówce wybranej przez siebie, po akceptacji opiekuna praktyk w macierzystej szkole.

Dyrektor szkoły lub wyznaczona przez dyrektora osoba powinna pomoc uczniowi w znalezieniu odpowiedniego zakładu pracy, który przyjmie ucznia na praktykę zawodową $\mathrm{w}$ terminie umożliwiającym realizację programu nauczania.

- Wsparcie rozwoju zawodowego ucznia udzielane przez opiekuna praktyk zawodowych

Praktyki zawodowe są prowadzone w zakładach pracy pod kierunkiem opiekunów praktyk, którymi mogą być sami pracodawcy lub wyznaczeni przez nich pracownicy tych zakładów. Warto dostrzegać, że opiekun praktyki może w relacji z uczniem pełnić funkcję coucha. Ramy treściowe i strukturę czasową spotkań coachingowych określa program praktyki zawodowej. Coaching zawodowy pomaga uczniom-praktykantom w wykorzystywaniu posiadanych umiejętności - zdobytych także $\mathrm{w}$ nauczaniu teoretycznych przedmiotów zawodowych - do realizacji zadań w obrębie danego zawodu, a także w rozwijaniu nowych, konkretnych umiejętności i wiedzy technicznej know-how tak, aby praktykant mógł sprostać wymaganiom pracy i osiągać lepsze efekty działania. Dzięki profesjonalnej pomocy i wsparciu opiekunów praktyk-coachów uczniowie-praktykanci wykształcają umiejętność ukierunkowanego działania, elastyczność myślenia i działania, elastyczność zachowań, pozbywają się schematów, wykształcają poczucie odpowiedzialności za własny rozwój i osiągane wyniki, lepiej rozumieją samego siebie, własne potrzeby i aspiracje. Cokolwiek jeszcze powie się o korzyściach płynących z coachingu, to jednak okazuje się, że zastosowanie coachingu zawodowego jest zasadne i może przynieść oczekiwane rezultaty, jeżeli ucznia charakteryzuje potrzeba samorealizacji, gotowość do rozwoju, motywacja do doskonalenia się. Uczeń-praktykant w relacji coachingowej musi odczuwać chęć rozwoju zawodowego, z akcentem na samokształcenie i samodoskonalenie. 
- Oferowanie przez szkoły kursów umożliwiających uczniom uzyskanie uprawnień zawodowych

Absolwenci szkół zawodowych nie mają uprawnień do wykonywania określonych prac. Ukończenie kursów umożliwiających uzyskanie uprawnień zawodowych wymaganych do wykonywania niektórych prac może poprawić ich zatrudnialność. Uprawnienia dotyczą umiejętności nieujętych w programie zajęć lub takich, dla których egzamin potwierdzający kwalifikacje zawodowe, także w zakresie danej kwalifikacji wyodrębnionej w ramach zawodu, nie stanowi wystarczającego poświadczenia kwalifikacji. Uzyskanie uprawnień jest możliwe tylko po ukończeniu kursu i zdaniu egzaminu na własny koszt, na koszt pracodawcy (o ile ten będzie chciał zatrudnić osobę bez uprawnień i ponieść koszty ich uzyskania) lub na koszt urzędu pracy. Ostatnie rozwiązanie wymusza rejestrację absolwenta w urzędzie pracy jako bezrobotnego.

Nabywanie konkretnych uprawnień powinno być włączone do procesu kształcenia szkolnego. Szkoła powinna prowadzić kursy prowadzące do uzyskania uprawnień zawodowych do wykonywania określonych prac i ponosić koszty ich uzyskania.

- Wspomaganie absolwentów szkół w pozyskaniu i utrzymaniu pracy, wsparcie społeczne w miejscu pracy

W poszukiwaniu zatrudnienia w konkretnej organizacji i na konkretnym stanowisku pożądana jest pomoc specjalisty ds. rekrutacji pracowników psychologa w rozpoznaniu, na ile formalne wykształcenie, ale przede wszystkim cechy osobowościowe kandydata na pracownika są zgodne z charakterem i warunkami wykonywania pracy, którą zamierza on podjąć. Istotny brak tej zgodności uniemożliwi lub ograniczy ewentualność samorealizacji przez pracę i osiągania satysfakcji z jej wykonywania.

Im większa odpowiedzialność związana z pracą, do której pretenduje kandydat, tym większa rola psychologa w procesie pozyskiwania pracy przez odpowiedniego pracownika. Ważne jest bowiem nie tylko rozpoznanie kwalifikacji formalnych, ale też predyspozycji i cech psychicznych kandydata do pracy. Z tych powodów proces rekrutacji i selekcji bywa wieloetapowy. W praktyce dość często zaniedbywany bywa trzeci i ostatni etap doboru pracowników, czyli proces adaptacji zawodowej. Nowy pracownik bywa rzucony na "głęboką wodę", czyli ma sobie sam radzić, co w dużej firmie, a nawet w średniej, nie jest łatwe. Co ważniejsze, nie zawsze jest to sprawdzianem cennych dla firmy kompetencji pracownika. I tak, śmiały, pewny siebie nowy pracownik może się łatwo odnaleźć w dużej firmie, ale nie ma szczególnie 
cennych dla niej kompetencji. Inny, bardziej zamknięty w sobie, nieśmiały, posiadający bardzo rzadkie i cenne kompetencje, ale rzucony na "głęboką wodę", bez opiekuna w początkowej fazie pracy, może czuć się zagubiony, niepotrzebny i rozczarowany. Zrezygnuje z pracy i - być może - zasili szeregi bezrobotnych, a firma wiele na tym straci - wskazuje S. Borkowska ${ }^{19}$. Rozpoznanie kompetencji oraz uwarunkowań sytuacyjnych pracownika (np. sytuacji rodzinnej, miejsca zamieszkania i in.) stanowi podstawę trafnego kształtowania ścieżek karier zawodowych.

Dla nowo przyjętego pracownika ważne i użyteczne jest wsparcie, pomoc, rady, opieka starszego, bardziej doświadczonego pracownika. Ten opiekun pełni rolę swoistego mentora. Demonstrowane przez niego zachowania stanowią wzorzec do naśladowania. Mentoring jest to bardzo użyteczna metoda wdrażania do pracy nowo zatrudnionego pracownika. Mentorem może być osoba o większym doświadczeniu, zajmująca wyższe stanowisko, która może służyć podopiecznemu radą, udzielać mu wskazówek i wsparcia tak, aby dopomóc mu w podnoszeniu poziomu wykonywania pracy. Mentor może nie tylko wywierać wpływ na to, w jakich szkoleniach i programach rozwoju zawodowego uczestniczy jego podopieczny, ale także w nieformalny sposób przekazywać mu pewną wiedzę. Jednocześnie pomaga podopiecznemu w rozwoju kariery zawodowej oraz budowaniu samoświadomości.

Wzrost wymagań wobec pracowników, konieczność stawiania czoła rosnącej konkurencji, nowym technologiom i postępującej globalizacji, presja na kreatywność, samodzielność i odpowiedzialność nie pozostaje bez wpływu na obciążenie psychiczne pracowników, staje się źródłem stresu, częstokroć długotrwałego i szkodliwego dla zdrowia. Tak więc, w toku wykonywania pracy $\mathrm{w}$ organizacji może być potrzebna pomoc $\mathrm{w}$ przeciwdziałaniu stresowi lub łagodzeniu jego skutków. Wsparcie społeczne w miejscu pracy udzielane przez przełożonych i współpracowników spełnia ważną funkcję łagodzenia stresu. Pojęcie „wsparcie społeczne w miejscu pracy” używa się, na przykład, „w odniesieniu do dobrych, przyjaznych relacji z innymi, dostępności innych w wypadku problemów oraz pomocy, zrozumienia i uwagi, na jakie jednostka może liczyć w razie trudności" ${ }^{20}$. Trudno przecenić znaczenie wsparcia społecznego $\mathrm{w}$ miejscu pracy dla zapobiegania stresowi lub łagodzenia skutków oddziaływania stresorów zawodowych wobec nowo

${ }^{19}$ S. Borkowska, Psychologiczne i organizacyjne aspekty zarzadzania zasobami ludzkimi, [w:] Rynek pracy, s. 213-214.

${ }^{20}$ P.L. Blanc, J. de Jonge, W. Schaufeli, Stres zawodowy a zdrowie pracowników, [w:] Psychologia pracy i organizacji, red. N. Chmiel, przekł. A. Kacmajor, M. Kacmajor, A. Nowak, S. Pikiel, A. Sulak, A. Tyszkiewicz, Gdańsk 2003, s. 190. 
zatrudnionych absolwentów szkół. Dobry klimat organizacyjny, przyjazne relacje zawodowe z przełożonymi i współpracownikami, przekonanie, że można liczyć na bezpośrednią pomoc lub wsparcie, informacje, rady, wskazówki i empatyczne zrozumienie ze strony innych łagodzi wpływ stresorów na reakcje stresowe i zmniejsza napięcie psychiczne. Wsparcie społeczne w miejscu pracy ze względu na jego treść może być wsparciem emocjonalnym (empatia, troska, zaufanie, zainteresowanie), wsparciem instrumentalnym (bezpośrednia pomoc ze strony innych osób), wsparciem informacyjnym (rady, informacje, sugestie, wskazówki), wsparciem oceniającym (informacje zwrotne lub porównania społeczne związane z samooceną danej osoby) $)^{21}$. Warto dodać, że te cztery typy wsparcia powinny uzupełniać się wzajemnie, aby pomagać nowo zatrudnionym pracownikom w przeciwdziałaniu stresowi lub w jego zwalczaniu. Jak już powiedziano wcześniej, fizyczny i psychiczny stan zdrowia determinuje jakość kapitału ludzkiego i przydatność do pracy właściciela owego kapitału.

Nietrudno dostrzec, że dla wielu osób praca stanowi istotną część życia. Z tego powodu należy uwzględniać ogromne ludzkie koszty stresu zawodowego podczas podejmowania decyzji dotyczących pracy. Do odniesień związanych z pojęciem pracy należy praktyka. Do każdego z tych dwóch pojęć można dodać - działalność. Praca jest zawsze jakąś praktyką. Praktyka jest zawsze jakąś pracą. Praktykę można umyślnie zaprojektować w celu dydaktycznym, w celu wyposażenia ucznia w komplet struktur umiejętnościowych, koniecznych do prawidłowego wykonywania zadań zawodowych. Wsparcie społeczne w miejscu pracy jest potrzebne pracującym absolwentom, a także w miejscu praktyki zawodowej uczniom przygotowującym się do pracy.

Konkludując, kapitał ludzki można powiększać za pomocą inwestycji w człowieka. Opłacalne są takie inwestycje w człowieka, w kapitał ludzki, które kształtują kompetencje cenione i przydatne na rynku pracy. Myślenie, iż młodzi ludzie nie oczekują zwrotu nakładów poniesionych na poprawę jakości rynkowej ich kapitału ludzkiego byłoby wielką naiwnością. Młodzi ludzie pytają, z jakich powodów nie mogą doczekać się rynkowego sukcesu. Oni także w przebiegu ich ścieżek edukacyjnych i zawodowych oczekują i potrzebują różnych form działań pomocowych - wsparcia i pomocy ze strony doradcy zawodowego, nauczyciela, instruktora praktycznej nauki zawodu, specjalisty ds. rekrutacji pracowników, specjalisty ds. szkolenia i rozwoju zawodowego, pracodawcy/przełożonego i współpracowników - które prowadzą do tworzenia i powiększania ich kapitału ludzkiego, ich konkurencyjności i szans bycia zatrudnionym.

${ }^{21}$ Tamże, s. 191. 


\section{BIBLIOGRAFIA}

Becker G.S., Ekonomiczna teoria zachowań ludzkich, przekł., H. Hagemejerowa, K. Hagemejer, Państwowe Wydawnictwo Naukowe, Warszawa 1990.

Blanc P.L., de Jonge J., Schaufeli W., Stres zawodowy a zdrowie pracowników, [w:] Psychologia pracy i organizacji, red. N. Chmiel, przekł. A. Kacmajor, M. Kacmajor, A. Nowak, S. Pikiel, A. Sulak, A. Tyszkiewicz, Gdańskie Wydawnictwo Psychologiczne, Gdańsk 2003.

Borkowska S., Psychologiczne i organizacyjne aspekty zarzadzania zasobami ludzkimi, [w:] Rynek pracy $i$ wykorzystanie potencjatu pracy w Polsce, red. A. Rajkiewicz, J. Orczyk, Instytut Pracy i Spraw Socjalnych, Warszawa 2014.

Buttler D., Studenci, pracodawcy, wykładowcy - różne wizje kompetentnego pracownika, Edukacja Ekonomistów i Menadżerów, 2012, 3(25).

Denek K., Ku dobrej edukacji, Wydawnictwo Edukacyjne AKAPIT, Torun 2005.

Górniak J. (red.), Kompetencje jako klucz do rozwoju Polski, Polska Agencja Rozwoju Przedsiębiorczości, Warszawa 2012.

GUS, Wybory ścieżki kształcenia a sytuacja zawodowa Polaków, Warszawa 2013.

Gruza M., Zatrudnialność absolwentów szkót zawodowych, [w:] Unowocześnianie metod i form ksztatcenia zawodowego w Polsce. Diagnoza i oczekiwane kierunki zmian, red. U. Jeruszka, Instytut Pracy i Spraw Socjalnych, Warszawa 2012.

Frieske K.W., Kapitat ludzki: teoria czy doktryna? [w:] Rynek pracy i wykorzystanie potencjatu pracy $w$ Polsce, red. A. Rajkiewicz, J. Orczyk, Instytut Pracy i Spraw Socjalnych, Warszawa 2014.

Jeruszka U. (red.), Unowocześnianie metod i form kształcenia zawodowego. Diagnoza i oczekiwane kierunki zmian, Instytut Pracy i Spraw Socjalnych, Warszawa 2012.

Juchnowicz M., Sektorowe badania podaży i popytu na kwalifikacje i kompetencje, Edukacja Ekonomistów i Menadżerów, 2014, 2(32).

Kabaj M., Projekt systemu integracji edukacji zawodowej i rynku pracy. W kierunku ksztatcenia dualnego, Polityka Społeczna, 1998, 9.

Kabaj M., Wptyw systemów kształcenia na zatrudnienie i bezrobocie młodzieży, Instytut Pracy i Spraw Socjalnych, Warszawa 2012.

Kiersztyn A., Racjonalne inwestycje czy złudne nadzieje: nadwyżka wykształcenia na polskim rynku pracy, Polityka Społeczna, 2011, 1.

Kryńska E., Kwiatkowski E., Podstawy wiedzy o rynku pracy, Wydawnictwo Uniwersytetu Łódzkiego, Łódź 2013.

Malewski M., Od nauczania do uczenia się. O paradygmatycznej zmianie w andragogice, Wydawnictwo Naukowe Dolnośląskiej Szkoły Wyższej, Wrocław 2010.

Mcguinness S., Overeducation in the Labour Market, Journal of Economic Surveys, 2006, 20.

Oleksyn T., Zarządzanie kompetencjami. Teoria i praktyka, Oficyna Ekonomiczna, Kraków 2006.

Pervin L.A., John O.P., Osobowość. Teoria i badania, New York 2001 (wyd. polskie: Wydawnictwo Uniwersytetu Jagiellońskiego), Kraków 2002.

Pocztowski A., Strategiczne aspekty rozwoju zasobów ludzkich, [w:] Przyszłość pracy w XXI wieku, red. S. Borkowska, Instytut Pracy i Spraw Socjalnych, Warszawa 2004.

Sienkiewicz Ł., Gruza M., Badanie kwalifikacji i kompetencji oczekiwanych przez pracodawców od absolwentów ksztatcenia zawodowego, GHK Consulting Ltd., Warszawa 2009. 